\title{
INFLUENCE OF GAP SHAPE ON BIOMECHANICAL PROPERTIES OF EXTRA-ARTICULAR DISTAL HUMERAL FRACTURE - A FINITE ELEMENT STUDY
}

\author{
Srećko Sabalić ${ }^{1}$ Hrvoje Maričić ${ }^{2}$ Zvonimir Tomičević ${ }^{2}$ and Janoš Kodvanj²
}

${ }^{1}$ Sestre milosrdnice University Hospital Center, University Hospital for Traumatology; ${ }^{2}$ Faculty of Mechanical Engineering and Naval Architecture, University of Zagreb, Zagreb, Croatia

\begin{abstract}
SUMMARY - The aim of the study was to assess the influence of gap shape on biomechanical results in extra-articular distal humeral fracture: with contact on the posterior part (by anterior gap) and contact on ulnar column (by radial gap). The goal was to examine if and to what extent did displacements decrease in comparison with previously examined parallel gap without bony contact. The finite element analysis on the three different plate constructs was performed, i.e. parallel, perpendicular and newly designed $Y$ shape plate were considered. Displacements were measured on articular surface and gap point. The most visible decrease of maximum displacements in the distal part of the model was detected in the Y plate model with axial loading: in case of anterior gap 58.5\% and especially at radially formed gap $60.9 \%$. Similarly, at axial loading, displacement at the analyzed point on fracture gap most significantly decreased in Y plate model (by 49.4\%) at posterior bony contact. Moreover, the latter showed displacement decrease by $68.5 \%$ at ulnar bone contact. Furthermore, if a longer radial plate than the ulnar one was used, varus stress could have been avoided. Study results suggested that sufficient stability could be ensured with the newly designed Y shape plate.
\end{abstract}

Key words: Humeral fractures - surgery; Fracture fixation, internal; Biomechanical phenomena; Finite element analysis; Bone plates

\section{Introduction}

Fractures of distal humerus in adults are often challenging in operative treatment. In practice, it has been shown that $16 \%$ of humeral shaft and $10 \%$ of distal humerus fractures in adults are distal humeral shaft and extra-articular supracondylar humerus fractures $^{1}$. The focus of this article is comminuted extraarticular distal humeral fracture. This type of fracture often results from a gunshot wound (Fig. 1) or motor vehicle injuries in the younger population ${ }^{2}$. Such injuries can also result from a simple fall in the elderly population $^{3}$. Although Y shape plate ${ }^{4,5}$ has been used for years in the treatment of intra-articular distal hu-

Correspondence to: Srećko Sabalić, $M D, P h D$, Medveščak 85, HR10000 Zagreb, Croatia

E-mail: ssabalic@gmail.com

Received March 15, 2016, accepted September 2, 2016 meral fracture, with a few modifications with two dorsal plates ${ }^{6}$ or distal part of Y shape plate ${ }^{7}$ Lambda $^{\circledR}$ plate, Zimmer, Étupes, France), it is not frequently used in the treatment of extra-articular distal humeral fracture and distal shaft fracture.

The aim of this study was to preconfigure the old $\mathrm{Y}$ reconstructive plate intended primarily for the treatment of intra-articular fractures of distal humerus and to convert it for extra-articular fractures of distal humerus and distal humeral diaphysis, as well as to examine its biomechanical performance comparing it to the existing osteosynthesis methods with two reconstruction plates in perpendicular and parallel position using the finite element method.

The principal objective of treating extra-articular distal humeral fractures is restoring alignment and achieving stable fixation aimed at facilitating early elbow range of motion, essential for good functional 

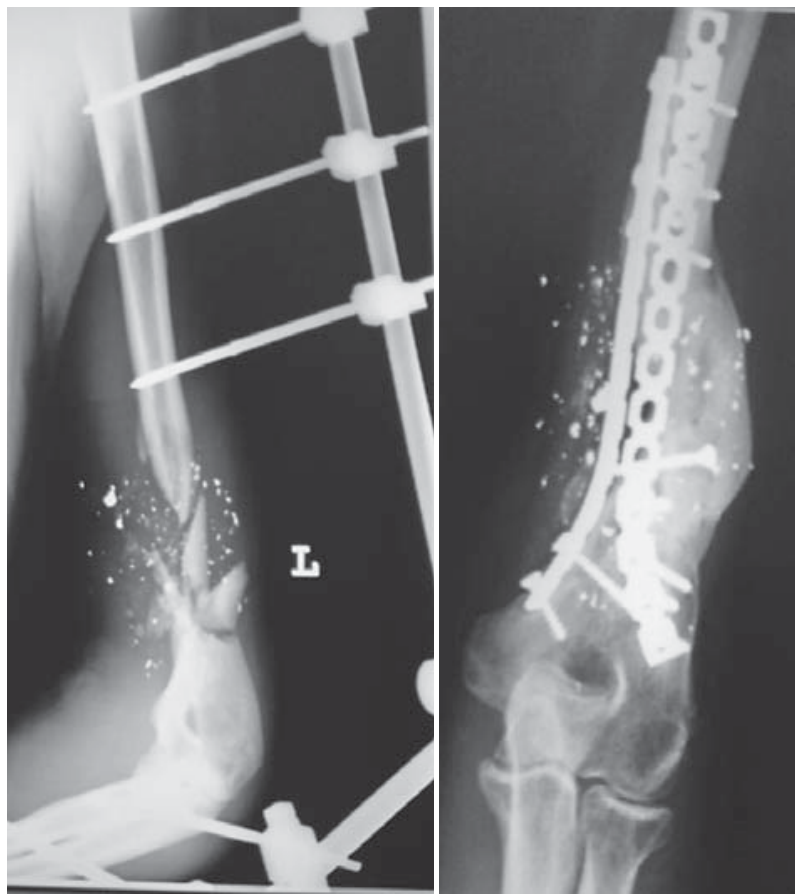

Fig. 1. Gunshot fracture of distal humerus: (left) treated with an external fixator; and (right) later treated with two plates in perpendicular position (90-90\%).

outcome. It is often difficult to obtain rigid fixation in distal fractures of humeral diaphysis without compromising the elbow ${ }^{8}$. However, fixation of these fractures remains a challenge due to the restricted space for instrumentation at the distal segment and the need to maintain repair integrity under a large range of motion and low to moderate loading.

Through many stages of development, from conservative to operative treatment, open reduction and internal fixation with dual plating systems are the gold standard for fixation of distal humerus fractures s,3,6,8-17. $^{2}$. Double-plating techniques using two $3.5 \mathrm{~mm}$ reconstruction plates or LCP plates in dorsal plating, $90-90^{\circ}$ or $180-180^{\circ}$ (Fig. 2) pattern are generally accepted for both intra-articular, ${ }^{3,8,10-16,18-23}$ and extra-articular fractures ${ }^{1-3,9,10,17}$. Previous studies have shown that surgery surpasses the results of conservative treatment ${ }^{3,8}$. Scolaro et al. ${ }^{24}$ in a recent biomechanical study suggest that single posterolateral column fixation of extra-articular humerus fractures is appropriate for more proximal fractures. However, it has been reported that the treatment with dual plate fixation is more suitable for distal fractures.
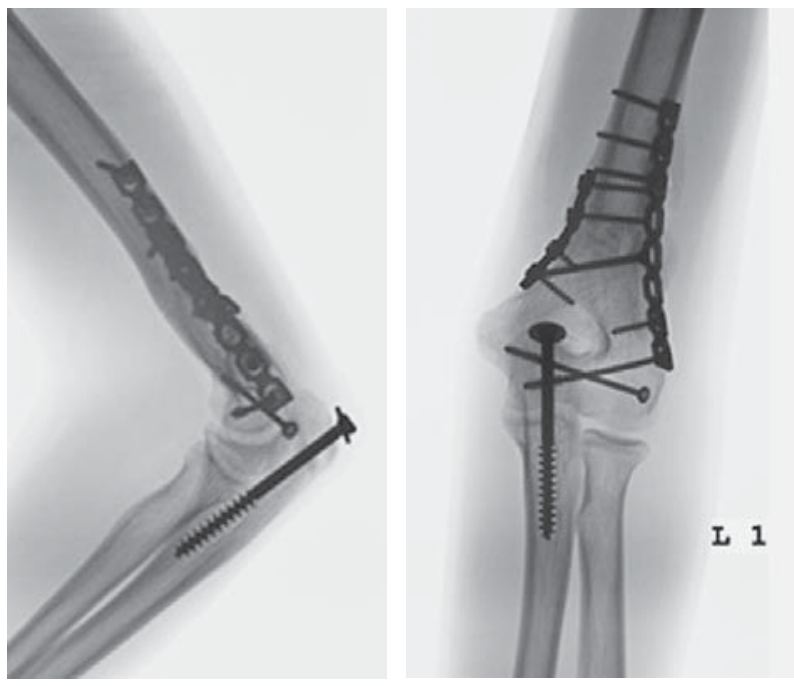

Fig. 2. Double-plating technique using two 3.5-mm reconstruction plates in parallel (180-180 ) configuration.
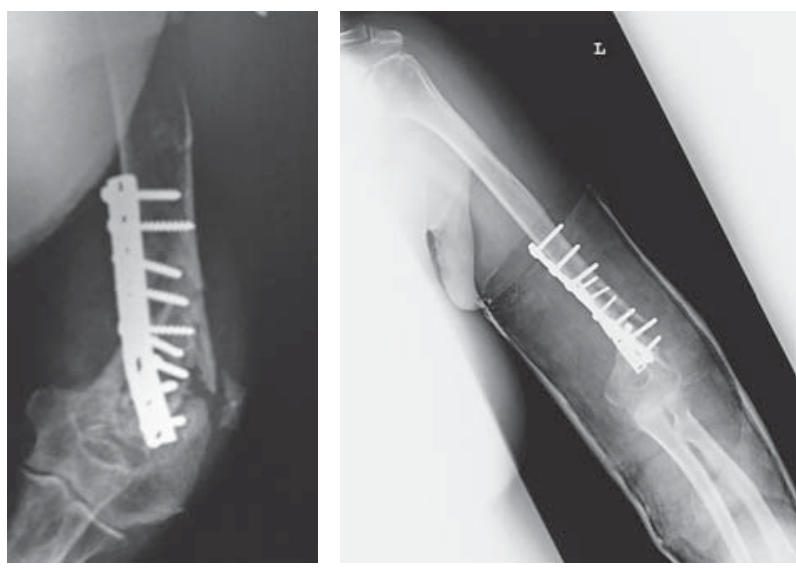

Fig. 3. Varus deformity after non-union of the extraarticular distal humeral fracture after osteosynthesis: (left) with one plate; and (right) with two plates.

Even if the above mentioned techniques are applied, this does not exclude non-union as a complication of distal humerus fractures, with a reported incidence of $8 \%$ to $25 \%{ }^{14}$. Poor initial fixation, which is not easily manageable in the presence of extensive comminution and osteopenia, can be the main factor for hardware failure ${ }^{25}$.

Migration of the plate and screws or non-union with cubitus varus deformity (gunstock deformity) can occur when applied to inadequate osteosynthesis with one plate (Fig. 3). 
In a previous study, by using the finite element calculations, attempts were made to find the optimal plate configuration which would improve its biomechanical properties, taking into account the specific anatomy of distal humerus ${ }^{26}$.

The article presents the effect of the gap shape in case of extra-articular distal humerus fracture on biomechanical properties. The finite element calculations are used to simulate these phenomena. In the first study, models with parallel gap ${ }^{26}$ were investigated, while the goal of this study was to examine whether contact in the posterior part (by anterior gap) and contact on ulnar column (by radial gap) influenced biomechanical properties.
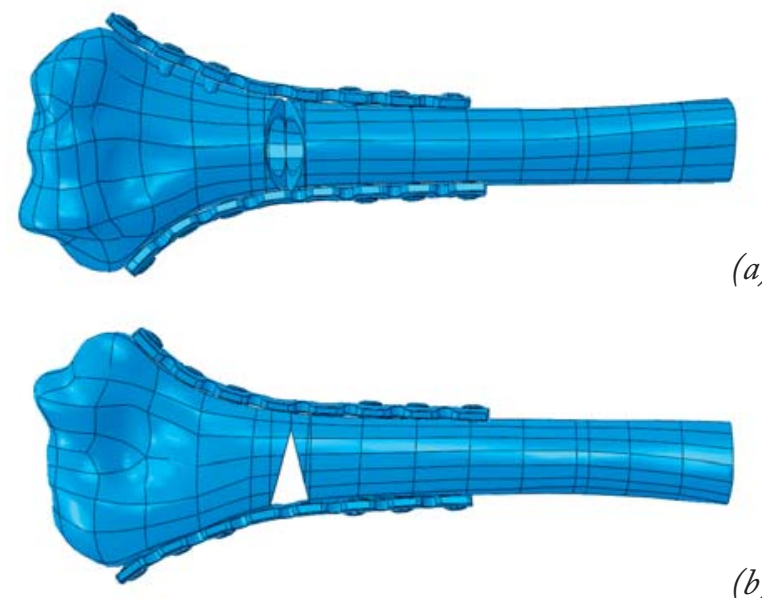

Fig. 4. Computational model: (a) with anterior gap; and (b) with radial gap.

\section{Materials and Methods}

The finite element analysis was performed on the three different plate constructs. Two different gaps placed $25 \mathrm{~mm}$ above the olecranon fossa were taken into account. First, anterior gap and bony contact in posterior segment were investigated, while the second one dealt with radial gap and bony contact in ulnar segment (Fig. 4). The creation of numerical models and the prescribed boundary, as well as the loading conditions are described in detail in Sabalic et al. ${ }^{26}$. Therefore, this article only briefly depicts them.

The finite element models of distal humerus with the newly designed Y plate and two 3.5 reconstruction plates in parallel and perpendicular configuration were created from 3D optical scans (Atos III Triple Scan, GOM mbH, Germany). Each model was $140 \mathrm{~mm}$ long and constrained with respect to the proximal end. The loading conditions of the models were the same as those previously used ${ }^{26}$. Nonlinear computational simulations under axial $(200 \mathrm{~N})$, lateral and bending (30 $\mathrm{N})$ loading regimes were conducted using the finite element software Abaqus 6.10-1 (Dassault Systèmes, France). In all finite element models, contact interactions were applied as surface to surface finite sliding with a coefficient of friction of 0.3 . The contact is defined between the bone and the plates and the connection of osteotomy interfaces. Tied constraints were applied between the screws and plates, as well as between the screws and the surrounding bone in all constructs. All models were meshed using ten node quadratic tetrahedral elements. The number of elements in the pro-

Fig. 5. Maximum displacements on the distal end of the models.

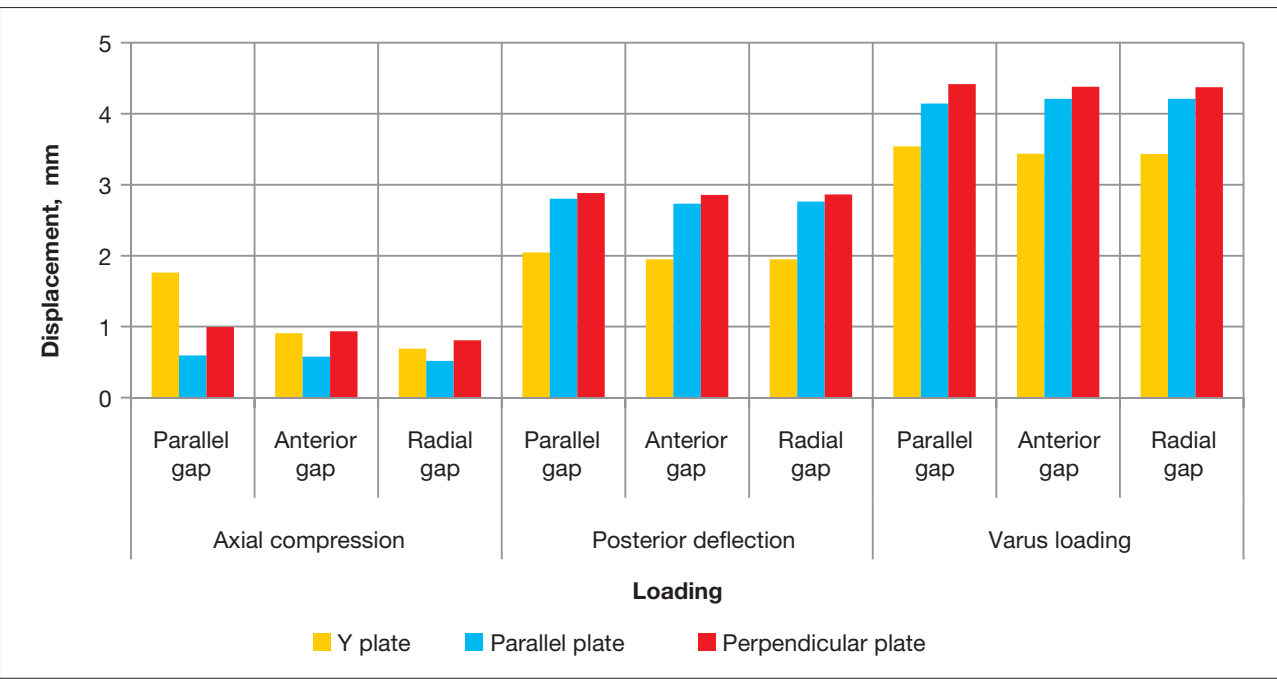


posed models altered from 796100 to 884200 elements depending on the plate type and number of screws.

The chosen material was defined as linear elastic, homogeneous and isotropic. The Poisson's ratio for osteoporotic bone was taken to be 0.4 . Young's modules applied for the cortical bone in axial compression, posterior deflection and varus loading were $3400 \mathrm{MPa}$, $1150 \mathrm{MPa}$ and $660 \mathrm{MPa}$, respectively. Both stainless steel and titanium alloys were assigned with a Poisson's ratio of 0.3, while the Young's module for steel equals $200 \mathrm{GPa}$ and for titanium $110 \mathrm{GPa}$.

\section{Results}

In the following section, the calculation results for the three different plate designs are reported. Figure 5 shows the maximum computed displacements on the distal end for the investigated plate models subjected under three different loading directions (i.e. axial,

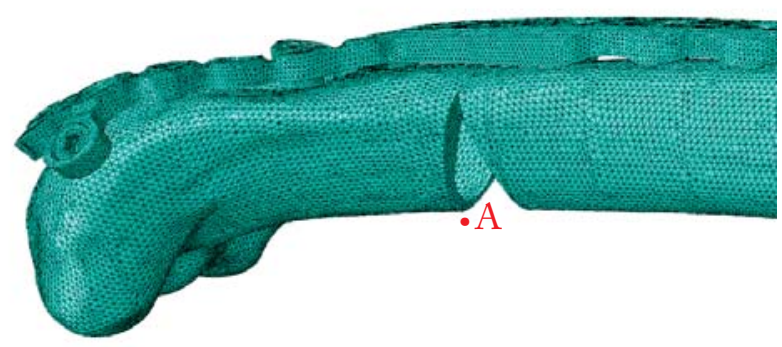

Fig. 6. Point $A$ on the distal edge of the fracture gap. bending and lateral direction) when the gaps were positioned $25 \mathrm{~mm}$ above the olecranon fossa and defined as parallel, radial and anterior.

Displacements on the fracture gap for all models are observed at point A (Fig. 6), due to the reasons mentioned earlier ${ }^{26}$. Maximum displacements at point A on the distal edge of the fracture gap for all the tests are reported in Figure 7. Estimated maximum stress levels in the bones and plates for the three investigated plate designs subjected under various loading regimes and gap definitions are shown in Table 1.

\section{Discussion}

By forming a gap in the segment of distal humerus with cortical bony contact using computational simulations we wanted to examine the influence of the gap shape on the biomechanical properties of the fracture in the segment of distal humerus in three methods of osteosynthesis. For this purpose, models from the previous study were used ${ }^{26}$. The aim was to examine if and to what extent the displacements decreased in comparison with previously examined parallel gap without bony contact.

The most visible decrease of maximum displacements in the distal part of the model was detected in the Y plate model with anterior gap at axial loading $(58.5 \%)$ and especially at radially formed gap $(60.9 \%)$. This was not detected in the models with parallel and perpendicular plate configuration. In all three models,

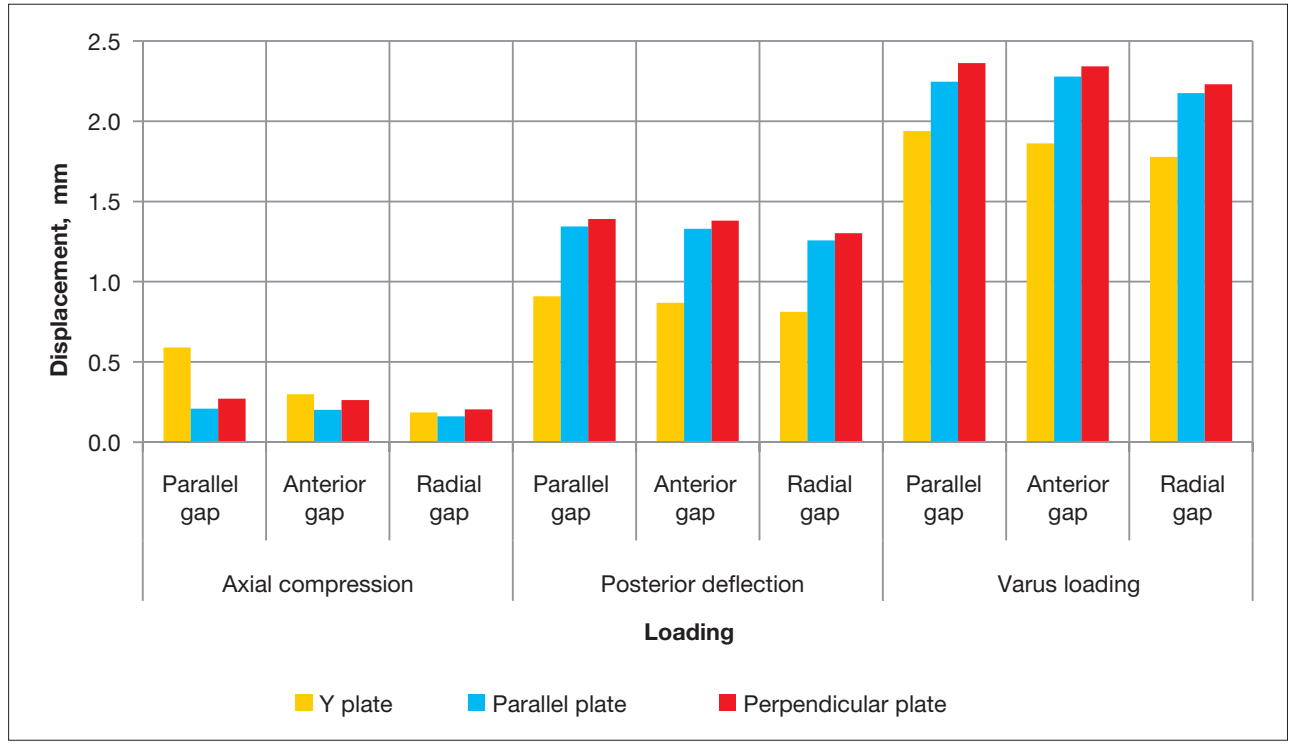

Fig. 7. Displacements in point $A$ on the distal edge of the fracture gap. 
Table 1. Maximum von Mises stresses in the bones and plates

\begin{tabular}{|c|c|c|c|c|c|c|c|c|c|c|}
\hline & \multicolumn{3}{|c|}{ Axial compression } & \multicolumn{3}{|c|}{ Posterior deflection } & \multicolumn{3}{|c|}{ Varus loading } \\
\hline & & $\begin{array}{c}\text { Parallel } \\
\text { gap }\end{array}$ & $\begin{array}{c}\text { Anterior } \\
\text { gap }\end{array}$ & $\begin{array}{l}\text { Radial } \\
\text { gap }\end{array}$ & $\begin{array}{l}\text { Parallel } \\
\text { gap }\end{array}$ & $\begin{array}{l}\text { Anterior } \\
\text { gap }\end{array}$ & $\begin{array}{l}\text { Radial } \\
\text { gap }\end{array}$ & $\begin{array}{l}\text { Parallel } \\
\text { gap }\end{array}$ & $\begin{array}{c}\text { Anterior } \\
\text { gap }\end{array}$ & $\begin{array}{l}\text { Radial } \\
\text { gap }\end{array}$ \\
\hline \multirow{2}{*}{ Parallel plate } & Bone & 10.86 & 14.42 & 22.46 & 13.98 & 15.02 & 15.09 & 14.12 & 20.51 & 23.64 \\
\hline & Plate & 309.40 & 173.30 & 152.40 & 143.10 & 119.60 & 140.30 & 160.80 & 153.60 & 153.60 \\
\hline \multirow{2}{*}{$\begin{array}{l}\text { Perpendicular } \\
\text { plate }\end{array}$} & Bone & 18.48 & 25.06 & 46.29 & 14.95 & 15.01 & 15.12 & 15.19 & 15.47 & 18.45 \\
\hline & Plate & 280.40 & 255.30 & 205.30 & 152.40 & 137.20 & 149.70 & 193.80 & 165.80 & 165.90 \\
\hline \multirow{2}{*}{ Y plate } & Bone & 25.01 & 32.56 & 48.49 & 14.87 & 15.37 & 15.42 & 16.54 & 22.58 & 22.67 \\
\hline & Plate & 567.40 & 276.80 & 160.30 & 189.00 & 221.10 & 220.90 & 189.00 & 83.66 & 83.68 \\
\hline
\end{tabular}

such visible changes were not detected at bending and lateral loading when compared to radial and anterior gap.

Similarly, at axial loading, the displacement at analyzed point A on fracture gap most significantly decreased in Y plate model (49.4\%) at dorsal bony contact, and by $68.5 \%$ at ulnar bone contact. In general, the shape of fracture gap, that is bony contact, did not have significant influence on displacements at bending and lateral loading of radial condyle, as in axial loading.

Significant stress changes were also detected in axial loading in terms of decreasing the stress in the plate and increasing the stress in the bone, in all three models. Stress decrease was most evident at axial loading of $Y$ plate, specifically in radial gap (354\%), with increase in the stress in bone (97\%). Such visible stress changes were not detected at bending, where stresses in Y plate in the models with anterior and radial gap were even greater than in the model with parallel gap. At lateral loading of Y plate model the stresses in the plate decreased (55.7\%), while bone stresses increased (36.7\%).

The current standard of treatment of the extra-articular distal humerus fracture is osteosynthesis with two plates in posteromedial and posterolateral position. Biomechanical stability on the transition of the distal humerus diaphysis into the distal segment of the humerus has been the object of several studies.

The incidence of distal humeral fracture is relatively low, with a large number of fracture subtypes. Clinical studies are often functionally insufficient because of the limited number of patients. There are no published prospective randomized studies, the majority of the studies were retrospective and carried out on a small number of samples. Therefore, on the basis of these clinical studies, it is not possible to draw conclusions about the recommendable implant configuration in case of fractures of distal humerus. A biomechanical study is therefore required ${ }^{26}$.

The majority of non-unions happen at the supracondylar level, while healing of the articular components may occur in their reduced position. Nonetheless, the stability of the construct requires adequate bony contact with interfragmentary compression. In case of a distal humeral fracture, by far the greatest number of fixation failures occurs at the supracondylar level, while typically the articular fragments unite, and, with time, fracture union occurs at this level.

Maximizing stability between the distal fragments and the shaft of the humerus at the metaphyseal level should be the focus of the fixation strategy $y^{7,10}$. O'Driscoll ${ }^{10}$ lists the technical principles to apply in order to achieve stable internal fixation of distal intraarticular humeral fractures.

From the previous research ${ }^{10}$ concerning the plates used for fixation, it has been reported that the latter should be applied in such a manner as to achieve compression at the supracondylar level for both columns. However, at the same time, the plates used must be strong and stiff enough to resist breaking or bending before union occurs at the supracondylar level.

The practical application of these principles involves 'parallel' plates that permit a total of at least 4 to 6 long screws to be placed in the distal fragments, from one side across to the other. The plates are placed with a slight offset, posteromedially and posterolaterally ${ }^{18}$.

Pajarinen et al..$^{27}$ conclude that satisfactory results can be obtained when the stability of the humeral columns is achieved and the articular platform reconstructed.

O'Driscoll ${ }^{10}$ points out that the literature on fractures of distal humerus pays far too little attention to the reason why the failure of the fixation generally be- 
gins in the lateral column. The force of gravity acting on the long lever arm (the forearm), while the elbow is flexed and extended during apparently minimal-use activities leads to repetitive varus stresses across the elbow. This can be typically seen in the action of a person reaching out to grab something, a glass of water for instance, followed by bringing the hand to the mouth. This causes varus torque across the elbow, distracting the lateral column away from the fixation placed along its posterior surface ${ }^{10}$.

The load transfer in the elbow joint can be described by a two column model ${ }^{1,28}$. The medial ulnar column and the lateral radial column form the articular block. The lateral column shares $60 \%$ and the medial column $40 \%$ of the load ${ }^{1,22,28}$. This two-column model is the basic principle of double plating osteosynthesis of C-type fractures of distal humerus ${ }^{1,10,16}$.

In recent publications, a higher stiffness and strength of osteosynthesis in the parallel plating technique were compared to the perpendicular technique with different plate designs. The mechanical advantages of a parallel plate configuration have been demonstrated for conventional reconstruction plate design ${ }^{29}$, as well as for locking plate construct ${ }^{23}$. In other studies, no significant differences were found ${ }^{1,9}$. As noted in previous studies, pseudoarthrosis of distal humerus usually occurs in the region at the metaphyseal and supracondylar level of radial columns due to varus stresses.

So far, there have been two biomechanical studies on the supracondylar metaphyseal level on the border of the distal humerus diaphysis. Except for these two ${ }^{24,26}$, previous studies examined intra-articular or low supracondylar fractures ${ }^{20-23,29}$.

In the proposed research, it is believed that fractures in this part of the humerus have different biomechanical demands than intra-articular fractures of distal humerus. The previously described new design of $Y$ shape plate, which supports both columns and is at the same time longer in the radial, more loaded column, could be at least equal in strength as the two plates.

To prove the hypothesis, the following tests should be performed: biomechanical studies at the supracondylar metaphyseal level on the border of the distal humerus diaphysis using the finite element method, where the gap would be done at the level of distal humerus $25 \mathrm{~mm}$ above the fossa olecrani (Fig. 4). The gap is shown in the figure as an interruption of the bone continuity.

The biomechanical study should be made to the axial load in a position of flexion of $5^{\circ}$, the bending load in a position of flexion of $75^{\circ}$ and the lateral load on the radial condyle. After applying the finite element computations in order to choose the optimal position of the plates, a biomechanical study of the synthetic or cadaver humerus would be undertaken. This study would compare the stiffness of the Y-shaped, parallel and perpendicular plate configuration by applying the same loads as those applied in the finite element analysis.

In their publication Penzkofer et al. ${ }^{1}$ state the following: “... the system stiffness is influenced by two kinds of factors: factors which cannot be influenced by the surgeon and factors which allow the individual adjustment of an osteosynthesis. The initial situation is the fracture pattern and fracture geometry with the number and shape of the fragments. This initial fracture situation strongly dictates the options for plate positioning. On the other hand, the overall construct stability can largely be influenced by placing the plates at different anatomical positions". This study did not take into account the lateral load, as there is already a load in the position of flexion and extension.

Furthermore, Zalavras et al. ${ }^{23}$ found that parallel plate designs had significantly higher stiffness than the perpendicular ones during cyclic varus loading. The measurement of displacement was not made by precise measuring instruments at the gap. In this article, loosening of the implants was defined as gross displacement (backing-out) of the screws during cyclic loading of the specimens. When done, varus loading to failure resulted in ligamentous disruption in all specimens, which occurred prior to any catastrophic failure of fixation ${ }^{19}$. In this way, they could not see displacements in the gap and assess the mechanical stability of the specimens.

Recent biomechanical studies have considered loads on the distal segment of the humerus in a position of flexion of $75^{\circ 2,23}$ or $50^{\circ}{ }^{24}$ to the longitudinal axis of the humerus, or a position of flexion of $5^{\circ 2}$ or $15^{\circ}{ }^{22}$. However, Zalavras et al. ${ }^{24}$ conducted experiments with radial varus loads.

In clinical studies, significantly better results were achieved with surgical than with conservative treatment of extra-articular distal humeral fracture ${ }^{3,11}$. Shin et al. ${ }^{17}$ compared clinical outcomes in patients with intra-articular distal humerus fractures and concluded that both parallel and orthogonal plate positioning could provide adequate stability and anatomic reconstruction of the distal humerus fractures, while Sanchez-Sotelo et al..$^{16,18}$ preferred the parallel configuration. 
Prasarn et al. ${ }^{8}$ have recently reported their good clinical experience with the use of the locking compression plate for extra-articular fractures of distal humerus, adding two additional reconstructive plates to the radial column. Consequently, Scolaro et al..$^{24}$ support this good clinical experience with relevant biomechanical study.

As noted in previous studies, pseudarthrosis of distal humerus usually occurs in the region of the metaphyseal and supracondylar level of the radial columns due to various stresses.

Previous studies have been differently designed with different directions and types of loads, i.e. various static and dynamic forms were applied with different cycles on a wide range of different samples. Furthermore, measuring instruments and their degree of precision in measuring displacements and deformations are different and hardly comparable. Therefore, it is difficult to compare the results of biomechanical studies. Also, so far, displacements in different directions when loads are significantly different have not been taken into account. Therefore, we believe that the direction of the load which causes greater displacements has a greater impact on the overall evaluation of the stability of the implant. Consequently, displacements caused by bending and lateral loads compared to the radial condyle are considerably larger than the axial load, and thus with a greater significance in the overall assessment of the structural stability of implants. Therefore, the role of the implant is to minimize the forces that cause greater displacements in the area. Likewise, in the case of osteoporotic fractures, we should know that osteoporosis is more pronounced in the posterolateral part of the radial condyle ${ }^{26}$, and that the area of the lateral columns, especially the capitulum and the distal part of the lateral column, has very thin cortices ${ }^{31}$.

A disadvantage of biomechanical studies of this kind is the inability to take into account all factors that influence treatment outcome. Among them, dynamic loads that occur during everyday activities have an important place.

The well known issue of anatomical variations in distal humerus requires making plates of different size with the ability of remodeling according to anatomical differences.

\section{Conclusion}

The biomechanical study proposed in this work provides a proof of the hypothesis that the two plates model where the plate at the radial side is longer results in better biomechanical stability in comparison with two plates of equal length in fractures of distal humerus diaphysis at the turn of the distal humerus. Furthermore, it has been shown that a newly designed Y shape plate, as described previously, provides biomechanical stability as the two plate model.

In order to avoid varus stress, radial plate should be longer than the ulnar plate. Sufficient stability can be ensured with the newly designed $\mathrm{Y}$ shape plate with the longer radial arm. Improving biomechanical stability would avoid complications such as pseudarthrosis or malunion.

The newly designed $Y$ plate for extra-articular fractures of distal humerus is a possible alternative to the usual osteosynthesis method with two plates. A definitive conclusion would require biomechanical studies, either with a synthetic or cadaveric model.

\section{References}

1. Penzkofer R, Hungerer S, Wipf F, von Oldenburg G, Augat P. Anatomical plate configuration affects mechanical performance in distal humerus fractures. Clin Biomech (Bristol, Avon). 2010 Dec;25(10):972-8. http://dx.doi.10.1016/j.clinbiomech.2010.07.005

2. Tejwani NC, Murthy A, Park J, McLaurin TM, Egol KA, Kummer FJ. Fixation of extraarticular distal humerus fractures using one locking plate versus two reconstruction plates: a laboratory study. J Trauma. 2009 Mar;66(3):795-9. http://dx. doi: 10.1097/TA.0b013e318181e53c

3. Robinson CM, Hill RM, Jacobs N, Dall G, Court-Brown CM. Adult distal humeral metaphyseal fractures: epidemiology and results of treatment. J Orthop Trauma. 2003 Jan;17(1):38-47. http://dx doi:10.1097/00005131-200301000-00006

4. Smrkolj V, Korošec B. Intra-articular fractures of the distal humerus. Acta Chir Iugosl. 1991;38(1):69-75.

5. Luegmair M, Timofiev E, Chirpaz-Cerbat JM. Surgical treatment of $\mathrm{AO}$ type $\mathrm{C}$ distal humeral fractures: internal fixation with a Y-shaped reconstruction (Lambda) plate. J Shoulder Elbow Surg. 2008;17:113-20. http://dx,. doi: 10.1016/j.jse. 2007.04.007

6. Bogataj M, Kosel F, Norris R, Krkovic M, Brojan M. Biomechanical study of different plate configurations for distal humerus osteosynthesis. Med Biol Eng Comput. 2015 May; 53(5):381-92. http://dx. doi: 10.1007/s11517-015-1247-1

7. Saragaglia D, Rouchy RC, Mercier N. Fractures of the distal humerus operated on using the Lambda ${ }^{\circledR}$ plate: report of 75 cases at 9.5 year follow-up. Orthop Traumatol Surg Res. 2013 Oct;99(6):707-12. http://dx. doi: 10.1016/j.otsr.2013.04.007

8. Prasarn ML, Ahn J, Paul O, Morris EM, Kalandiak SP, Helfet DL, Lorich DG. Dual plating for fractures of the distal third of 
the humeral shaft. J Orthop Trauma. 2011 Jan;25(1):57-63. http://dx. doi: 10.1097/BOT.0b013e3181df96a7

9. Schwartz A, Oka R, Odell T, Mahar A. Biomechanical comparison of two different periarticular plating systems for stabilization of complex distal humerus fractures. Clin Biomech (Bristol, Avon). 2006 Nov;21(9):950-5. http://dx.doi.org/10. 1016/j.clinbiomech.2006.04.018

10. O'Driscoll SW. Optimizing stability in distal humeral fracture fixation. J Shoulder Elbow Surg. 2005;14:186S-94. http:// dx.doi.org/10.1016/j.jse.2004.09.033

11. Jawa A, McCarty P, Doornberg J, Harris M, Ring D. Extraarticular distal-third diaphyseal fractures of the humerus. A comparison of functional bracing and plate fixation. J Bone Joint Surg Am. 2006 Nov;88(11):2343-7. http://dx.doi: 10.2106/JBJS.F.00334

12. Schatzker J. Fractures of the distal End of the humerus (13-A, $\mathrm{B}$ and C). In: Schatzker J, Tile M (Eds). The Rationale of Operative Fracture Care. Springer, Berlin-Heidelberg-New York, 2005;103-121.

13. McKee MD. Fractures of the shaft of the humerus. In: Bucholz RW, Heckman JD, Court-Brown CM (Eds). Rockwood and Green's Fractures in Adults. Lippincott Williams \& Wilkins, Philadelphia; 2006;1117-59.

14. Becker EH, Stein J. Advancements in the treatment of distal humeral fractures. Curr Orthop Pract. 2009 Aug;20(4):345-8. http://dx doi: 10.1097/BCO.0b013e3181a65514

15. DeLuise A, Voloshin I. Current management of distal humerus fractures. Curr Opin Orthop. 2006;(17):340-7. http://dx. doi: 10.1097/01.bco.0000233730.49010.c5

16. Sanchez-Sotelo J, Torchia ME, O'Driscoll SW. Complex distal humeral fractures: internal fixation with a principle-based parallel-plate technique. J Bone Joint Surg Am. 2007;89:961-9. http://dx.doiI: 10.2106/JBJS.E.01311

17. Shin SJ, Sohn HS, Do NH. A clinical comparison of two different double plating methods for intraarticular distal humerus fractures. J Shoulder Elbow Surg. 2010 Jan;19(1):2-9. http:// dx.doi: 10.1016/j.jse.2009.05.003

18. Sanchez-Sotelo J, Torchia ME, O'Driscoll SW. Principlebased internal fixation of distal humerus fractures. Tech Hand Up Extrem Surg. 2001 Dec;5(4):179-87. http://dx.doi: 00130911-200112000-00001

19. Theivendran K, Duggan PJ, Deshmukh SC. Surgical treatment of complex distal humeral fractures: functional outcome after internal fixation using precontoured anatomic plates. J Shoulder Elbow Surg. 2010 Jun;19(4):524-32. http://dx.doi: 10.1016/j.jse.2009.09.011

20. Korner J, Diederichs G, Arzdorf M, et al. A biomechanical evaluation of methods of distal humerus fracture fixation using locking compression plates versus conventional reconstruction plates. J Orthop Trauma. 2004;18:286-93. http://dx.doi: 10.1097/00005131-200405000-00004
21. Schuster I, Korner J, Arzdorf M, Schwieger K, Diederichs G, Linke B. Mechanical comparison in cadaver specimens of three different 90-degree double-plate osteosyntheses for simulated C2-type distal humerus fractures with varying bone densities. J Orthop Trauma. 2008;22:113-20. http://dx.doi:10.1097/ BOT.0b013e3181632cf8

22. Windolf M, Maza ER, Gueorguiev B, Braunstein V, Schwieger $\mathrm{K}$. Treatment of distal humeral fractures using conventional implants. Biomechanical evaluation of a new implant configuration. BMC Musculoskelet Disord. 2010 Aug 4;11:172. https://dx.doi.org/10.1186/1471-2474-11-172

23. Zalavras CG, Vercillo MT, Jun BJ, Otarodifard K, Itamura JM, Lee TQ. Biomechanical evaluation of parallel versus orthogonal plate fixation of intra-articular distal humerus fractures. J Shoulder Elbow Surg. 2011 Jan;20(1):12-20. http://dx.doi: 10.1016/j.jse.2010.08.005

24. Scolaro JA, Hsu JE, Svach DJ, Mehta S. Plate selection for fixation of extra-articular distal humerus fractures: a biomechanical comparison of three different implants. Injury. 2014 Dec;45 (12):2040-4. http://dx.doi: 10.1016/j.injury.2014.08.036

25. Sommer C, Babst R, Müller M, Hanson B. Locking compression plate loosening and plate breakage: a report of four cases. J Orthop Trauma.2004 Sep;18(8):571-7.http://dx.doi: 10.1097/ 00005131-200409000-00016

26. Sabalic S, Kodvanj J, Pavic A. Comparative study of three models of extra-articular distal humerus fracture osteosynthesis using the finite element method on an osteoporotic computational model. Injury. 2013 Sep;44 Suppl 3:S56-61. http://dx. doi:10.1016/S0020-1383(13)70200

27. Pajarinen J, Bjorkenheim JM. Operative treatment of type C intercondylar fractures of the distal humerus: results after a mean follow-up of 2 years in a series of 18 patients. J Shoulder Elbow Surg. 2002;11:48-52. https://dx.doi.org/10.1067/ mse.2002.119390

28. Halls AA, Travill A. Transmission of pressures across the elbow joint. Anat Rec. 1964;150:243-7.

29. Arnander MW, Reeves A, MacLeod IA, Pinto TM, Khaleel A. A biomechanical comparison of plate configuration in distal humerus fractures. J Orthop Trauma. 2008 May-Jun;22 (5):332-6. http://dx. https://dx.doi.org/10.1097/BOT.0b013e 31816edbce

30. Park SH, Kim SJ, Park BC, Suh KJ, Lee JY, Park CW, Shin IH, Jeon IH. Three-dimensional osseous micro-architecture of the distal humerus: implications for internal fixation of osteoporotic fracture. J Shoulder Elbow Surg. 2010 Mar;19(2):244-50. http://dx.doi: 10.1016/j.jse.2009.08.005

31. Diederichs G, Issever AS, Greiner S, Linke B, Korner J. Threedimensional distribution of trabecular bone density and cortical thickness in the distal humerus. J Shoulder Elbow Surg. 2009 May-Jun;18(3):399-407. https://dx.doi.org/10.1016/j. jse.2008.11.001 
Sažetak

\section{UTJECAJ OBLIKA PUKOTINE NA BIOMEHANIČKA SVOJSTVA EKSTRAARTIKULARNIH PRIJELOMA DISTALNOG HUMERUSA - STUDIJA METODOM KONAČNIH ELEMENATA}

\section{S. Sabalic, H. Maričic, Z. Tomičevič i J. Kodvanj}

Cilj ovoga rada bio je procijeniti utjecaj oblika pukotine na biomehaničke rezultate kod extraartikularnih prijeloma distalnog humerusa s kontaktom na stražnjem dijelu (procijepom u prednjem dijelu) i s kontaktom na ulnarnoj kolumni (procijepom na radijalnom dijelu). Cilj je bio ispitati smanjuju li se i u kojoj mjeri pomaci u usporedbi s prethodno ispitanim paralelnim procijepom bez koštanog kontakta. Provedene su računalne simulacije metodom konačnih elemenata na modelima s paralelnom i perpendikularnom konfiguracijom rekonstrukcijskih pločica i s novodizajniranom Y pločicom. Mjerenja su izvršena na zglobnoj plohi i u mjernoj točki na distalnom rubu pukotine. Najizraženije smanjenje maksimalnih pomaka bilo je kod Y ploče pri aksijalnom opterećenju s procijepom u prednjem dijelu $(58,5 \%)$, a osobito s radijalnim procijepom $(60,9 \%)$. Slično, pri aksijalnom opterećenju smanjenje pomaka u analiziranoj točki na frakturnoj pukotini bilo je najizraženije kod Y pločice $(49,4 \%)$ s dorzalnim kontaktom i ulnarnim koštanim kontaktom $(68,5 \%)$. Kako bi se izbjegla varusna naprezanja, radijalna ploča treba biti duža od ulnarne. Studija ukazuje na to da se dostatna stabilnost može osigurati novodizajniranom Y pločicom.

Ključne riječi: Humerus, frakture - kirurgija; Frakture, fiksacija; Biomehanički fenomeni; Metoda konačnih elemenata; Kost, fiksacija plocicom 